Демидов О. А., Гудзенко В. М., Правдзіва І. В., Василенко Н. В., Дергачов О. Л., Заїма О.А.

УДК 633.111.1:631.58

ФОРМУВАННЯ ТА ВАРІАБЕЛЬНІСТЬ НАТУРНОӤ МАСИ ЗЕРНА

ГЕНОТИПІВ ПШЕНИЦІ М'ЯКОЇ ОЗИМОЇ (Triticum aestivum L.)

ЗАЛЕЖНО ВІД УМОВ РОКУ, ПОПЕРЕДНИКІВ ТА СТРОКІВ СІВБИ

О. А. ДЕМИДОВ, доктор сільськогосподарських наук, професор, директор, завідувач відділу зернових культур

E-mail: mwheats@ukr.net

В. М. ГУДЗЕНКО, доктор сільськогосподарських наук, старший науковий співробітник, заступник директора з наукової роботи, завідувач лабораторії селекції ячменю

E-mail: barley22@ukr.net

I. В. ПРАВДЗІВА, в.о. завідувача лабораторії якості зерна E-mail: irinapravdziva@gmail.com

Н. В. ВАСИЛЕНКО, науковий співробітник лабораторії якості зерна E-mail: vasylenkonv147@gmail.com

О. Л. ДЕРГАчОВ, кандидат сільськогосподарських наук, старший науковий співробітник відділу насінництва та агротехнологій

E-mail: adergachev012@gmail.com

О. А. ЗАЇМА, кандидат сільськогосподарських наук, старший науковий співробітник відділу насінництва та агротехнологій

E-mail: oleksii.zaima@ukr.net

Миронівський інститут пиениці імені В.М. Ремесла НААН Украӥни https://doi.org/10.31548/dopovidi2021.03.005

Анотація. Метою дослідження було виявити особливості формування та варіабельності натурної маси зерна генотипів пшениці м'якої озимої залежно від умов року, строку сівби та різних попередників. Дослідження проведено в Миронівському інституті пшенищі імені В. М. Ремесла НААН Украӥни упродовж 2016/17-2018/19 рр. Оцінили 17 генотипів пшениці м'якої озимої, висіяні у три строки сівби після n'яти попередників. Натуру зерна визначали згідно з ГОСТ 10840-64. Статистичну обробку даних проводили з використанням програм Statistica 8.0, Excel 2013.Виявлено суттєвий вплив умов року вирошування на натуру зерна сортів пиениці м'якої озимої в умовах изентрального Лісостепу України. Відзначено достовірні відмінності за реакцією досліджених генотипів на строки сівби після різних попередників. Встановлено найбільиий вплив строків сівби на натуру зерна у сорту МІП Відзнака, попередників - у сортів МІП Ювілейна, Подолянка, МІП Лада, МІП Дарунок. Загалом, максимальною натура зерна була після попередника сидеральний пар, найменша - після сой. Виявлено загальну тенденцію зменшення натури зерна зі зміщенням строку сівби від 26 вересня до 16 жовтня після попередників сидеральний пар, гірчиця, соняшник, соя. Оптимальним був строк сівби 5 жсовтня для сортів МІП 
Демидов О. А., Гудзенко В. М., Правдзіва І. В., Василенко Н. В., Дергачов О. Л., Займа О.А.

Валенсія, Естафета миронівська, МІП Лада після попередника сидеральний пар; після гірчиці - для сортів Подолянка, Трудівницяя миронівська, Грачія миронівська, МІП Дніпрянка, МІП Лада; після соняшнику - сортів Подолянка, Трудівничя миронівська, Балада миронівська, Грація миронівська, МІП Ассоль; після кукурудзи - сортів Трудівниця миронівська, Естафета миронівська; після сої - Подолянка, Трудівниця миронівська. Виділено сорти МІП Вишиванка, Трудівниия миронівська, Балада миронівська, Естафета миронівська, МІП Дніпрянка, МІП Відзнака та МІП Ювілейна, які достовірно переважали стандарт Подолянка за натурою зерна в середньому за роками досліджень, строками сівби та попередниками.

Ключові слова: пшениця м'яка озима, натура зерна, строк сівби, попередник, $A N O V A$

Актуальність.

Пшениця

(Triticum aestivum L.) - одна 3 основних культур для харчування людства [1]. Зростання виробництва зерна, що відповідає вимогам світових стандартів за якісними показниками $\epsilon$ одним iз важливих завдань сільськогосподарської науки та виробництва. Натурна маса зерна (натура зерна) - один 3 основних показників, який характеризує фізичні властивості зерна [2] та входить до переліку класоутворюючих. Цей показник частково характеризує виповненість зерна й має важливе значення під час транспортування і його зберігання [3]. Чим більша натура тим більш виповнене зерно та вища його харчова цінність [4, 5]. Із зерна, що має більшу натуру отримують вищий вихід борошна [6-7]. За зниження натури зерна нижче 700 г/л погіршуються хлібопекарські властивості борошна та смакові якості хліба [8]. Рівень прояву натури зерна пшениці залежить від низки чинників: генетичних особливостей сорту, гідротермічних умов, технології вирощування, попередників тощо [3, 9].

Аналіз останніх досліджень та публікацій. Аналіз структури посівних площ сільськогосподарських культур в Україні за останні роки свідчить, що значну частину займають такі технічні культури, як соняшник, кукурудза, соя та ріпак [10]. Отже, очевидно, що велика частка площ посіву головної продовольчої зернової культури пшениці озимої розміщується саме після згаданих попередників. Різний термін збирання попередників у виробничих умовах, водний i температурний режим осіннього періоду потребує вивчення різних строків сівби озимих культур [4, 11, 12]. Ранні строки сівби призводять до переростання рослин унаслідок пізнього часу припинення вегетації в осінній період, призводять до зниження зимостійкості, а також вилягання й ураження збудниками 
Демидов О. А., Гудзенко В. М., Правдзіва І. В., Василенко Н. В., Дергачов О. Л., Займа О.А.

хвороб упродовж весняно-літньої вегетації. За пізніх строків сівби та пізнього відновлення весняної вегетації слабкі 3 осені рослини не можуть повністю компенсувати брак осіннього кущіння, що суттєво впливає на рівень врожайності та показники якості. Тобто, лише за сівби в оптимальні строки та після правильно підібраних попередніх культур для кожного сорту, можливо, отримати великі врожаї 3 високими показниками якості. Практичне значення має інформація, як щодо оптимального для кожного генотипу попередника та строку сівби, так i виділення генотипів із вищим рівнем стабільності за врожайністю та показниками якості після різних попередників та за різних строків сівби $[13 ; 14]$.

Мета дослідження - виявити особливості формування та варіювання натурної маси зерна генотипів пшениці м'якої озимої залежно від умов року, строку сівби та після різних попередників в умовах центральної частини Лісостепу України.

\section{Матеріал і методи дослідження. Дослідження} проведено в умовах Миронівського інституту пшениці імені В. М. Ремесла НААН України (МІП) у 2016/17-2018/19 рр. Матеріалом для досліджень були 17 сортів пшениці м'якої озимої: Подолянка (стандарт), МІП Валенсія, МІП Вишиванка, МІП Княжна, Трудівниця миронівська,
Балада миронівська,

Вежа миронівська, Грація миронівська, Естафета миронівська, МІП Ассоль, МIП Дніпрянка, Аврора миронівська, МІП Відзнака, МІП Дарунок, МІП Лада, МІП Фортуна, МІП Ювілейна (G1...G17) висіяні за трьох строків сівби (I - 26 вересня, II - 5 жовтня, III - 16 жовтня), після П’яти попередників (сидеральний пар (GM), гірчиця (MS), соя (SB), соняшник (SF), кукурудза (CR)).

Грунт селекційної сівозміни чорнозем глибокий (38-42 см), малогумусний, слабковилугований. Вміст гумусу в 20 см шарі грунту 3,6-4,5 \%, легкодоступного (легкогідролізованого) азоту - 0,06 г, фосфору - 0,25 г і обмінного калію 0,11-0,18 г на 1 кг грунту, $\mathrm{pH}-5,3-$ 6,4 , сума поглинутих основ - 0,230,29 г-екв. на 1 кг грунту, ступінь насичення основами - 86,2-94,4\%.

Агротехніка вирощування загальноприйнята для зони Лісостепу [15]. Сівбу здійснювали селекційною сівалкою СН-10 Ц на глибину 3-4 см iз нормою висіву 5 млн схожих насінин на 1 га. Ділянки розміщували за повною рандомізованою схемою в чотирьох повтореннях, 3 обліковою

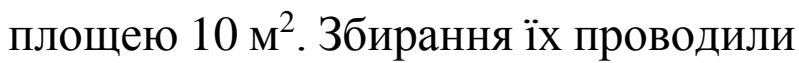
комбайном «Sampo-130».

Натуру зерна визначали за допомогою літрової пурки згідно 3 ГОСТ 10840-64 [16], відбираючи проби з кожного повторення. Різниця між паралельними визначеннями не перевищувала 5 г. $3 \mathrm{a}$ кінцевий 
Демидов О. А., Гудзенко В. М., Правдзіва І. В., Василенко Н. В., Дергачов О. Л., Займа О.А.

результат

приймали

середньоарифметичне значення двох вимірів 3 точністю до 1,0 г.

Статистичну обробку отриманих даних проводили за методами описової і варіаційної статистики, а також дисперсійного аналізу (ANOVA) 3 використанням програм Statistica 8.0, Excel 2013.

Результати дослідження та їх обговорення. Роки дослідження були контрастними за гідротермічним режимом iз нерівномірним розподілом опадів за місяцями (табл. 1). Середня температура повітря щороку перевищувала середню багаторічну (СБП) на 0,8$1,7{ }^{\circ}$ С. Найбільше варіювання середньомісячних температур за роками спостерігали переважно 3 листопада до березеня. Загалом до посушливих можна віднести 2016/17 i 2018/19 вегетаційні роки, а більш зволоженим був 2017/18 р. Сума опадів у ці роки становила відповідно $78 \%, 91 \%$ та $120 \%$ порівняно до СБП кількості. Особливо треба відмітити нестачу опадів у серпні в усі роки випробувань (в середньому менше на 36 мм до СБП кількості), у вересні 2016/17 p. і 2017/18 р. (відповідно на 48 та 37 мм менше СБП), у жовтні 2018/19 р. (на 18 мм менше СБП), у березні 2016/17 р. (на 22 мм менше до СБП кількості), у квітні 2017/18 р. і 2018/19 р. (відповідно на 20 та 18 мм менше до СБП), а також у травні 2016/17 p. і 2017/18 р. (відповідно на 28 і 18 мм менше СБП), у червні 2016/17 p. (на 59 мм менше СБП).

1. Середньомісячні значення гідротермічного режиму за період проведення досліджень, 2016/17-2018/19 рр.

\begin{tabular}{|c|c|c|c|c|c|c|c|c|c|c|c|c|c|}
\hline $\begin{array}{c}\text { Вегета- } \\
\text { ційний } \\
\text { рік }\end{array}$ & VIII & IX & X & XI & XII & I & II & III & IV & V & VI & VII & За рік \\
\hline \multicolumn{10}{|c|}{ Температура повітря, ${ }^{\circ}$ C } \\
\hline $2016 / 17$ & 21,1 & 15,7 & 6,7 & 1,4 & $-1,8$ & $-5,3$ & $-2,6$ & 6 & 10,4 & 15,4 & 20,6 & 20,9 & 9,0 \\
\hline $2017 / 18$ & 22,4 & 17 & 8,6 & 3,5 & 2,2 & $-2,9$ & $-3,6$ & $-1,8$ & 13,3 & 18,4 & 20,2 & 21,1 & 9,9 \\
\hline $2018 / 19$ & 22 & 16,7 & 10,6 & 0 & $-1,8$ & -5 & 0,3 & 4,6 & 10,4 & 17,4 & 22,7 & 19,6 & 9,8 \\
\hline СБП & $\mathbf{1 9 , 5}$ & $\mathbf{1 4 , 4}$ & $\mathbf{8 , 2}$ & $\mathbf{2 , 2}$ & $\mathbf{- 2 , 3}$ & $\mathbf{- 4 , 6}$ & $\mathbf{- 3 , 7}$ & $\mathbf{1 , 2}$ & $\mathbf{9 , 1}$ & $\mathbf{1 5 , 3}$ & $\mathbf{1 8 , 5}$ & $\mathbf{2 0 , 2}$ & $\mathbf{8 , 2}$ \\
\hline \multicolumn{10}{|c|}{ Сума опадів, мм } \\
\hline $2016 / 17$ & 37 & 2 & 75 & 44 & 31 & 31 & 33 & 12 & 43 & 23 & 20 & 102 & 453 \\
\hline $2017 / 18$ & 20 & 13 & 74 & 52 & 115 & 63 & 37 & 93 & 21 & 33 & 97 & 79 & 697 \\
\hline $2018 / 19$ & 15 & 89 & 28 & 22 & 72 & 40 & 26 & 27 & 23 & 50 & 87 & 50 & 529 \\
\hline СБП & $\mathbf{6 0}$ & $\mathbf{5 0}$ & $\mathbf{3 6}$ & $\mathbf{4 0}$ & $\mathbf{4 2}$ & $\mathbf{3 6}$ & $\mathbf{3 1}$ & $\mathbf{3 4}$ & $\mathbf{4 1}$ & $\mathbf{5 1}$ & $\mathbf{7 9}$ & $\mathbf{7 9}$ & $\mathbf{5 7 9}$ \\
\hline
\end{tabular}

Примітка: СБП - середній багаторічний показник (1980-2016 pp.) 
Демидов О. А., Гудзенко В. М., Правдзіва І. В., Василенко Н. В., Дергачов О. Л., Займа О.А.

Встановлено значну мінливість У середньому для всієї вибірки натури зерна пшениці озимої залежно генотипів після п’яти попередників за від гідротермічних умов років дослідження (рис. 1). Найбільшу варіабельність цього показника відмічено у 2016/17 р. (668-797 г/л), найменшу - у 2018/19 р. (757-824 г/л). трьох строків сівби максимальну (800 г/л) натуру зерна відмічено у 2018/19 р., найнижчу (741 г/л) - у $2016 / 17$ p. У 2017/18 р. Згаданий показник становив 753 г/л.

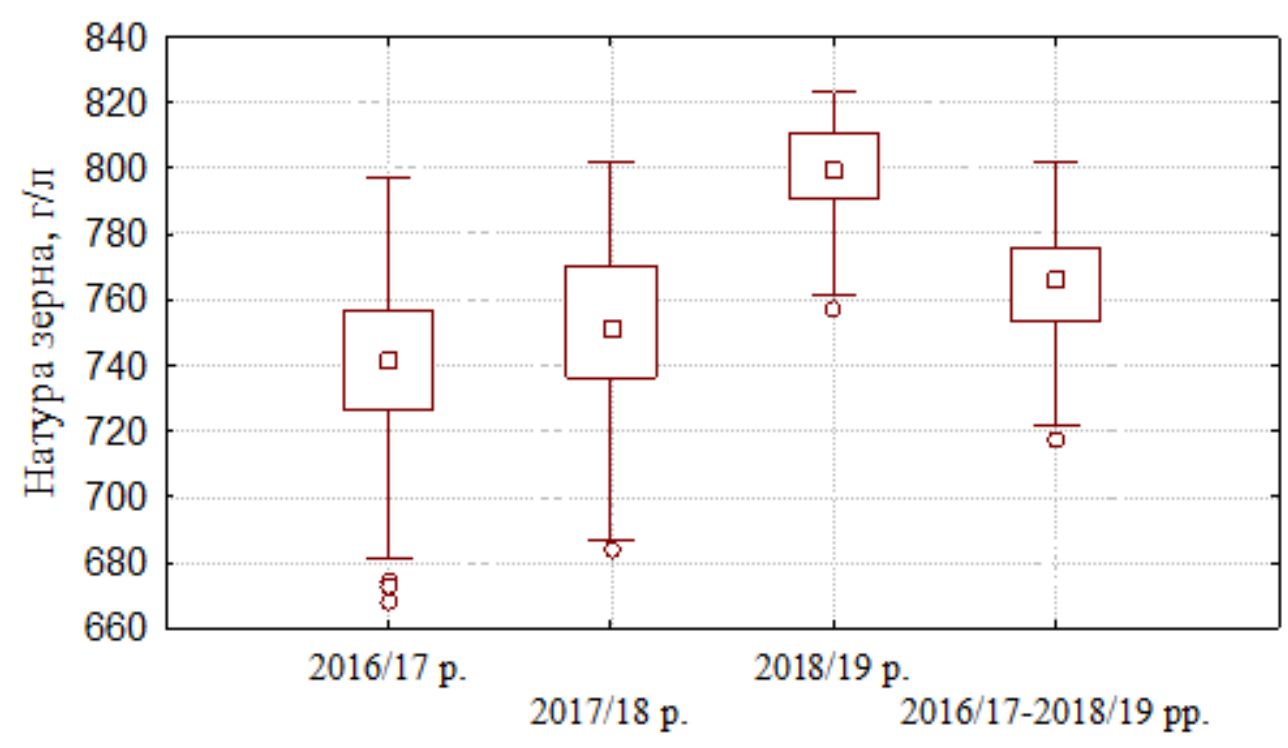

\section{Рис. 1. Варіювання натури зерна генотипів пшениці озимої залежно від умов року, г/л}

За результатами дисперсійного аналізу встановлено найбільший вплив на натуру зерна сортів пшениці м'якої озимої умов року вирощування $(58,8$ \%) (табл. 2) з внеском у загальну дисперсію (за середнім квадратом) $87,0 \%$. Частка генотипу становила $12,6 \%$, попередника - 9,4 \%. Достовірного впливу строків сівби на цей показник не відмічено. Виявлено значний $(6,9 \%)$ вплив взаємодії чинників рік $\times$ попередник, це свідчить про різний вплив попередніх культур на натуру зерна в роки вирощування. Найбільшу частку впливу умов року на цей показник отримано також в дослідах M. R. Parvej et al. [17]. Однак, за результатами О. В. Завадської та ін. [8] натура зерна залежить переважно від сортових особливостей. C.V. Valde's et al., M. Sobolewska et al. [6; 7] стверджують, що натура зерна залежить, як від сортових особливостей, так і від умов року. Про найменший вплив строків сівби на натуру зерна повідомляють A. Twizerimana et al. [18].

На основі дисперсійного аналізу в розрізі певних генотипів виявлено різне співвідношення впливу умов року, строку сівби та попередника для різних генотипів (табл. 3). Зокрема, частка умов року варіювала від 51,5 до 82,0 \%, попередника від 7,4 до 19,5 \%, строку 
Демидов О. А., Гудзенко В. М., Правдзіва І. В., Василенко Н. В., Дергачов О. Л., Займа О.А.

сівби від $0,02 \%$ до 5,2 \%, взаємодії сівби, рік $\times$ попередник $\times$ строк сівби чинників рік $\times$ попередник, рік $\times \quad(4,0-19,9 ; 0,1-2,9 ; 0,4-3,0 ; 1,2-11,1 \%$ строк сівби, попередник $\times$ строк відповідно).

2. Результати дисперсійного аналізу натури зерна генотипів пшениці м'якої озимої, 2016/17-2018/19 pр.

\begin{tabular}{|c|c|c|c|c|c|c|}
\hline Джерело варіації & $\mathrm{df}$ & SS & MS & F фак. & F теор. & $\begin{array}{c}\text { Частка } \\
\text { впливу, \% }\end{array}$ \\
\hline Загальна & 3059 & 3432035,5 & - & - & $1 \%$ & - \\
\hline Генотип (А) & 16 & 431549,1 & 26971,8 & 18230,1 & 2,01 & 12,6 \\
\hline Рік (B) & 2 & 2017483,7 & 1008741,9 & 681803,1 & 4,61 & 58,8 \\
\hline Попередник (C) & 4 & 322627,7 & 80656,9 & 54515,6 & 3,33 & 9,4 \\
\hline Строк сівби (D) & 2 & 9103,7 & 4551,9 & 3076,6 & 4,61 & 0,3 \\
\hline $\mathrm{A} \times \mathrm{B}$ & 32 & 84913,4 & 2653,5 & 1793,5 & 1,68 & 2,5 \\
\hline $\mathrm{A} \times \mathrm{C}$ & 64 & 35530,3 & 555,2 & 375,2 & 1,46 & 1,0 \\
\hline $\mathrm{A} \times \mathrm{D}$ & 32 & 16300,4 & 509,4 & 344,3 & 1,68 & 0,5 \\
\hline $\mathrm{B} \times \mathrm{C}$ & 8 & 237383,1 & 29672,9 & 20055,7 & 2,52 & 6,9 \\
\hline$B \times D$ & 4 & 2992,3 & 748,1 & 505,6 & 3,33 & 0,1 \\
\hline $\mathrm{C} \times \mathrm{D}$ & 8 & 7442,8 & 930,3 & 628,8 & 2,52 & 0,2 \\
\hline $\mathrm{A} \times \mathrm{B} \times \mathrm{C}$ & 128 & 69704,4 & 544,6 & 368,1 & 1,32 & 2,0 \\
\hline $\mathrm{A} \times \mathrm{B} \times \mathrm{D}$ & 64 & 28633,8 & 447,4 & 302,4 & 1,46 & 0,8 \\
\hline $\mathrm{B} \times \mathrm{C} \times \mathrm{D}$ & 16 & 40852,7 & 2553,3 & 1725,8 & 2,01 & 1,2 \\
\hline $\mathrm{A} \times \mathrm{C} \times \mathrm{D}$ & 128 & 40785,1 & 318,6 & 215,4 & 1,32 & 1,2 \\
\hline $\mathrm{A} \times \mathrm{B} \times \mathrm{C} \times \mathrm{D}$ & 256 & 83337,5 & 325,5 & 220,0 & 1,23 & 2,4 \\
\hline Невраховані фактори & 2295 & 3395,5 & 1,5 & - & - & 0,1 \\
\hline
\end{tabular}

Примітка: df - число ступенів свободи, SS - сума квадратів, MS - середній квадрат, F фак. - критерій Фішера фактичне значення, F теор. - критерій Фішера теоретичне значення

Виявлено дещо менший вплив попередника на натуру зерна сортів МІП Фортуна, Балада миронівська, Вежа миронівська, МІП Дніпрянка (7,4; 7,9; 8,0; 8,0 \% відповідно), найбільший - сортів МІП Ювілейна, Подолянка, МІП Лада, МІП Дарунок (відповідно 16,3; 18,3; 19,1; 19,5\%). Строки сівби суттєво впливали на цей показник лише сорту МІП Відзнака (5,2 \%), а в інших сортів частка впливу не перевищувала $1,3 \%$. Встановлено значну частку взаємодії чинників рік $\times$ попередник у сортів МІП Вишиванка, Подолянка, МІП Лада (відповідно 14,2; 16,9; $19,9 \%)$. 
Демидов О. А., Гудзенко В. М., Правдзіва І. В., Василенко Н. В., Дергачов О. Л., Заїма О.А.

3. Частка впливу (\%) факторів на натуру зерна сортів пшениці м'якої озимої, 2016/17-2018/19 pр.

\begin{tabular}{|c|c|c|c|c|c|c|c|c|}
\hline $\begin{array}{c}\text { Шифр } \\
\text { сорту }\end{array}$ & $\begin{array}{c}\text { Рік } \\
\text { (B) }\end{array}$ & $\begin{array}{c}\text { Поперед- } \\
\text { ник (C) }\end{array}$ & $\begin{array}{c}\text { Строк } \\
\text { (D) }\end{array}$ & BхC & BxD & СxD & ВхCxD & $\begin{array}{c}\text { Невраховані } \\
\text { фактори }\end{array}$ \\
\hline G1 & 55,8 & 18,3 & 1,3 & 16,9 & 0,6 & 1,2 & 5,8 & 0,1 \\
\hline G2 & 67,9 & 11,3 & 1,0 & 11,3 & 1,6 & 2,5 & 4,2 & 0,1 \\
\hline G3 & 69,0 & 11,9 & 0,2 & 14,2 & 0,5 & 0,8 & 3,3 & 0,1 \\
\hline G4 & 72,2 & 11,2 & 0,2 & 11,9 & 1,6 & 1,5 & 1,2 & 0,1 \\
\hline G5 & 82,0 & 8,8 & 0,5 & 4,0 & 0,3 & 0,4 & 3,9 & 0,1 \\
\hline G6 & 74,1 & 7,9 & 1,0 & 10,5 & 0,8 & 2,1 & 3,7 & 0,1 \\
\hline G7 & 77,9 & 8,0 & 1,1 & 7,4 & 1,3 & 1,2 & 3,0 & 0,1 \\
\hline G8 & 78,1 & 8,9 & 0,4 & 6,6 & 0,8 & 2,0 & 3,0 & 0,1 \\
\hline G9 & 75,1 & 12,7 & 0,8 & 5,5 & 1,2 & 1,6 & 3,0 & 0,1 \\
\hline G10 & 61,8 & 10,1 & 0,0 & 12,2 & 1,8 & 2,9 & 11,1 & 0,1 \\
\hline G11 & 79,5 & 8,0 & 0,2 & 5,6 & 0,2 & 2,1 & 4,3 & 0,1 \\
\hline G12 & 78,8 & 8,9 & 0,8 & 7,3 & 0,1 & 1,0 & 2,9 & 0,1 \\
\hline G13 & 62,6 & 13,6 & 5,2 & 5,4 & 2,9 & 2,1 & 8,0 & 0,2 \\
\hline G14 & 66,6 & 19,5 & 1,1 & 9,0 & 0,3 & 1,4 & 1,9 & 0,1 \\
\hline G15 & 51,5 & 19,1 & 0,3 & 19,9 & 2,0 & 3,0 & 4,1 & 0,1 \\
\hline G16 & 73,2 & 7,4 & 1,0 & 13,5 & 1,1 & 0,6 & 3,1 & 0,1 \\
\hline G17 & 72,4 & 16,3 & 1,1 & 5,2 & 0,6 & 0,9 & 3,4 & 0,1 \\
\hline
\end{tabular}

Примітка: G1 - Подолянка, G2 - МІП Валенсія, G3 - МІП Вишиванка, G4 - МIП Княжна, G5 - Трудівниця миронівська, G6 - Балада миронівська, G7 - Вежа миронівська, G8 - Грація миронівська, G9 - Естафета миронівська, G10 - МІП Ассоль, G11 - МІП Дніпрянка, G12 - Аврора миронівська, G13 - МІП Відзнака, G14 - МІП Дарунок, G15 - МІП Лада, G16 МІП Фортуна, G17 - МІП Ювілейна.

Максимальну (782 г/л) натуру зерна в середньому для всіх генотипів за 2016/17-2018/19 рр. отримали після попередника сидеральний пар, найменшу (753 г/л) - після сої (табл. 4). Схожу закономірність спостерігали і інші дослідники [14]. У дослідженнях R. Costaet al., A. Habibi et al. [4; 11] більшою була натура зерна за ранніх строків сівби. У той же час I. Г. Протопіш [19] наводить протилежні дані. У наших дослідженнях виявлено загальну тенденцію зменшення натури зерна зі зміщенням строку сівби від 26 вересня до 16 жовтня після попередників сидеральний пар, гірчиця, соняшник та соя (табл. 4).

Однак, для певних сортів така залежність не прослідковувалась (рис. 2). Виявлено, що для низки генотипів оптимальним був другий строк сівби після певних попередників. Зокрема, у середньому за роки досліджень істотно вищу натуру зерна за сівби 5 жовтня після попередника сидеральний пар сформували сорти МІП Валенсія (787 г/л), Естафета миронівська (802 г/л), МІП Лада (774 г/л); після 
Демидов О. А., Гудзенко В. М., Правдзіва І. В., Василенко Н. В., Дергачов О. Л., Заїма О.А.

гірчиці - Подолянка (773 г/л), миронівська (778 г/л), Грація Трудівниця миронівська (791 г/л), миронівська (752 г/л), МІП Ассоль Грація миронівська (766 г/л), МІП (755 г/л); після кукурудзи Дніпрянка (791 г/л), МІП Лада Трудівниця миронівська (779 г/л), (762 г/л); після соняшника - Естафета миронівська (777 г/л); після Подолянка (764 г/л), Трудівниця сої-Подолянка (754 г/л), Трудівниця миронівська (780 г/л), Балада миронівська (780 г/л).

4. Натура зерна (г/л) сортів пшениці м'якої озимої залежно від строків сівби та попередників, 2016/17-2018/19 pp.

\begin{tabular}{|c|c|c|c|c|c|c|}
\hline \multirow{2}{*}{ Строк сівби } & \multicolumn{5}{|c|}{ Попередник } & \multirow{2}{*}{ Середнє } \\
\cline { 2 - 6 } & GM & MS & SF & CR & SB & \\
\hline I & 785 & 774 & 760 & 759 & 756 & 767 \\
\hline II & 782 & 771 & 759 & 757 & 753 & 764 \\
\hline III & 778 & 767 & 757 & 761 & 750 & 763 \\
\hline Середнє & 782 & 770 & 759 & 759 & 753 & 765 \\
\hline HIP $_{05}$ & 2 & 4 & 2 & 2 & 3 & 3 \\
\hline
\end{tabular}

Примітка: GM - сидеральний пар, MS - гірчиця, SB - соя, SF - соняшник, CR - кукурудза. 810
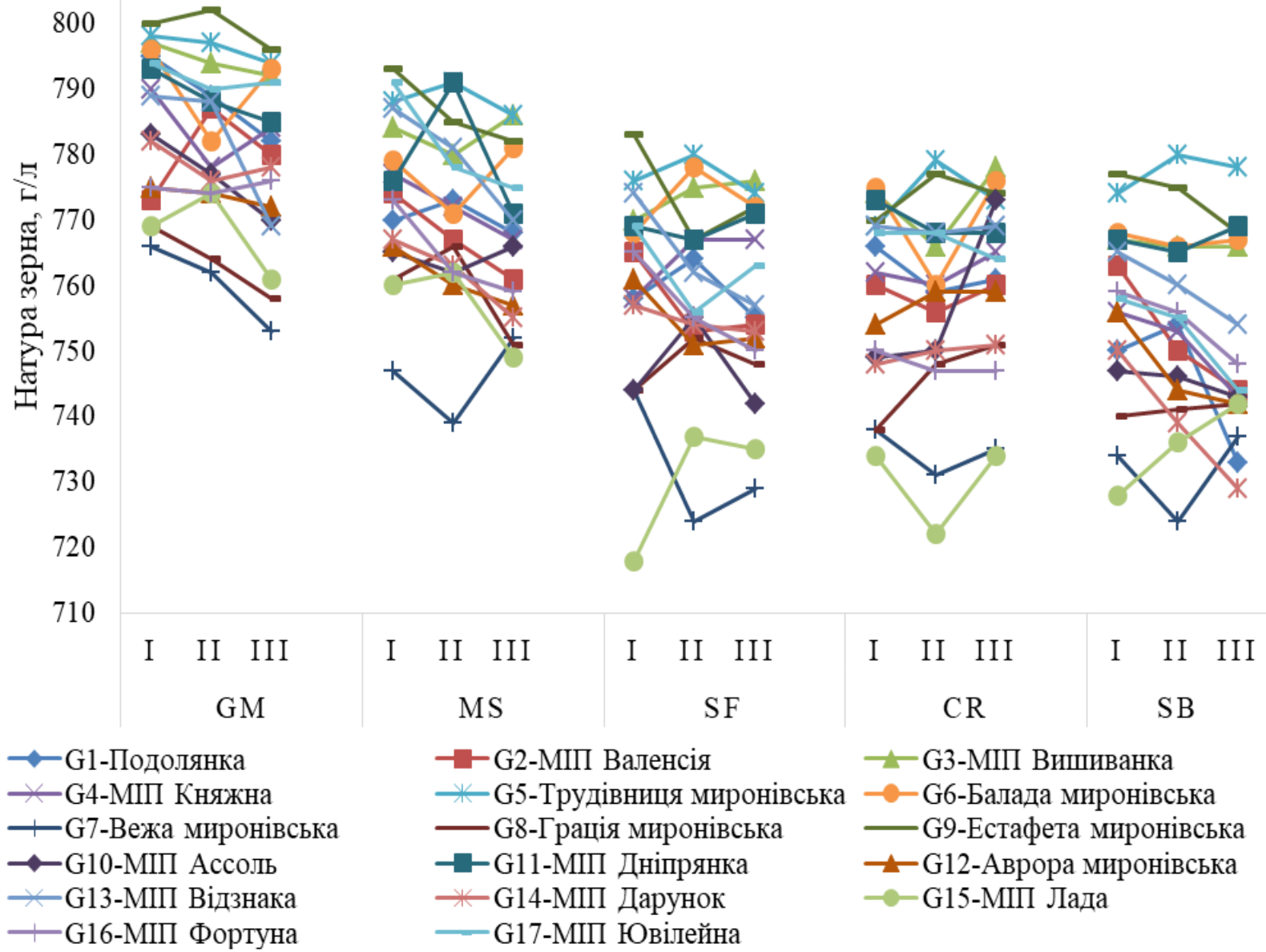

Примітка: GM - сидеральний пар, MS - гірчиця, SB - соя, SF - соняшник, CR кукурудза; I, II, III - строки сівби

Рис. 2. Натура зерна сортів пшениці м'якої озимої в середньому за роками залежно від строків сівби та попередників, 2016/17-2018/19 pр. 
Демидов О. А., Гудзенко В. М., Правдзіва І. В., Василенко Н. В., Дергачов О. Л., Заїма О.А.

У середньому за всіма (775 г/л), МІП Відзнака (771 г/л) та варіантами досліду в роки МIП Ювілейна (771 г/л) які випробування (рис. 3) виділено сорти достовірно переважали стандарт МІП Вишиванка (778 г/л), Трудівниця Подолянка (765 г/л). Сорт МІП миронівська (782 г/л), Балада Княжна був статистично на рівні миронівська (775 г/л), Естафета стандарту. миронівська (781 г/л), МІП Дніпрянка

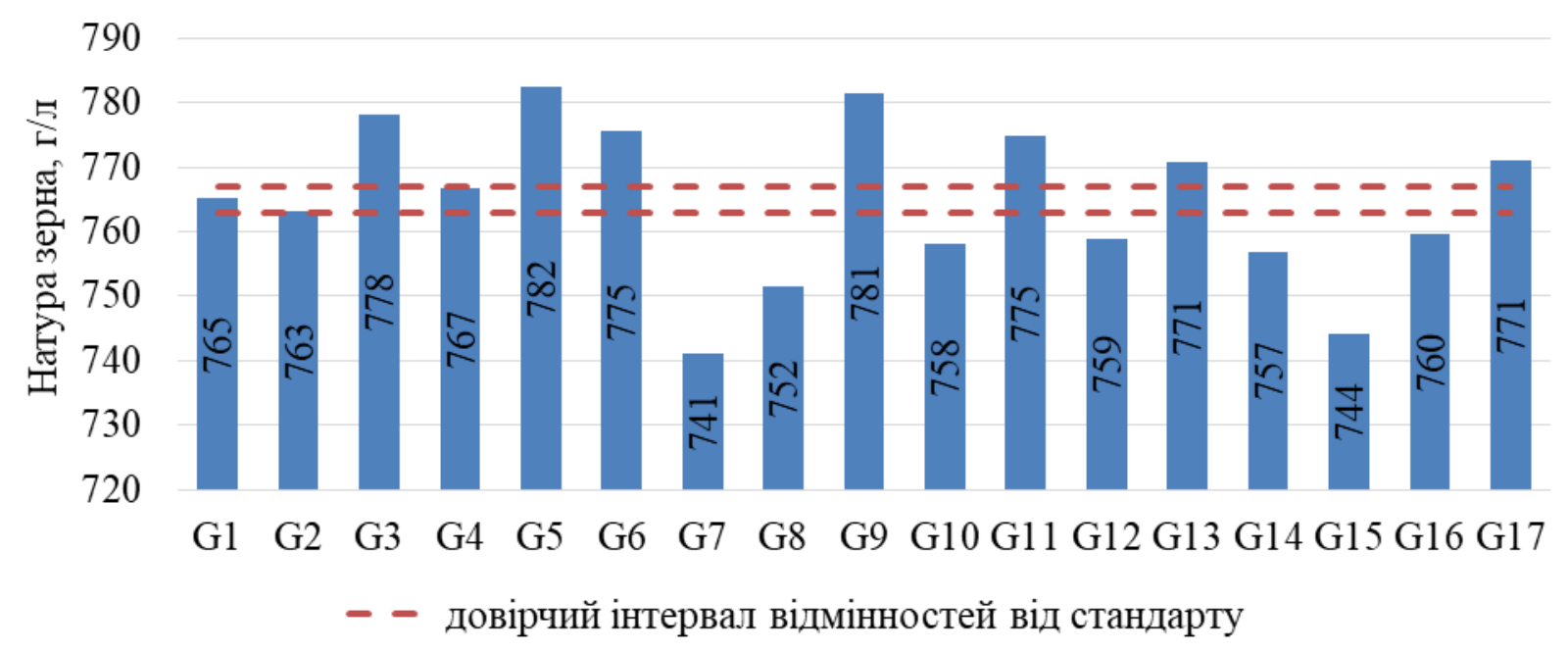

Примітка: G1 - Подолянка, G2 - МІП Валенсія, G3 - МІП Вишиванка, G4 - МIП Княжна, G5 - Трудівниця миронівська, G6 - Балада миронівська, G7 - Вежа миронівська, G8 - Грація миронівська, G9 - Естафета миронівська, G10 - МІП Ассоль, G11 - МІП Дніпрянка, G12 - Аврора миронівська, G13 - МІП Відзнака, G14 - МIП Дарунок, G15 - МІП Лада, G16 МІП Фортуна, G17 - МІП Ювілейна.

Рис. 3. Натура зерна сортів пшениці м'якої озимої в середньому за строками сівби та попередниками, 2016/17-2018/19 pр.

Висновки i перспективи. $\mathrm{y}$ результаті проведених досліджень встановлено найвищий вплив на формування натури зерна пшениці озимої умов року (58,8 \%), значний генотипу (12,6 \%) та попередника $(9,4 \%)$. Однак, для певних генотипів виявлено різне співвідношення впливу умов року (51,5-82,0 \%), строку сівби (0,02-5,2 \%) та попередника (7,4-19,5 \%). Максимальну (782 г/л) натуру зерна в середньому для всіх генотипів за роки дослідження відмічено після попередника сидеральний пар, найменшу (753 г/л) - після сої. Встановлено загальну тенденцію зменшення натури зерна зі зміщенням строку сівби від 26 вересня до 16 жовтня після попередників сидеральний пар, гірчиця, соняшник та соя. Однак, виявлено, що для певних генотипів після певних попередників оптимальним був другий строк сівби (5 жовтня). Виділено сорти МІП Вишиванка, Трудівниця миронівська, Балада миронівська, Естафета миронівська, 
Демидов О. А., Гудзенко В. М., Правдзіва І. В., Василенко Н. В., Дергачов О. Л., Займа О.А.

МІП Дніпрянка, МІП Відзнака та МІП

Ювілейна, які достовірно переважали

стандарт Подолянка за натурою зерна

\section{Список використаних джерел}

1. Denčić S., Mladeno N., Kobiljski B. Effects of genotype and environment on breadmaking quality in wheat. International Journal of Plant Production. 2011. Vol. 5, Iss. 1. P. 71-82.

2. Улянич І. Ф. Круп'яні властивості зерна пшениці м'якої озимої залежно від сорту. Збірник наукових праць Уманського НУС. 2020. Вип. 96. Част.1. С. 572-582.

3. Deivasigamani S., Swaminathan C. Evaluation of seed test weight on major field crops. International Journal of Research Studies in Agricultural Sciences (IJRSAS). 2018. Vol. 4, Iss. 1. P. 8-11.

4. Costa R., Pinheiro N., Almeida A. S., Gomes C., Coutinho J., Coco J., Costa A., Maçãs B. Effect of sowing date and seeding rate on bread wheat yield and test weight under Mediterranean conditions. Emir. J. Food Agric. 2013. Vol. 25, Iss. 12. P. 951-961.

5. Личко Н. М. Стандартизация и подтверждение соответствия сельскохозяйственной продукции. Учебник для вузов. Москва: ДеЛи плюс, 2013. 512с.

6. Valde's C. V., Estrada-Campuzano G., Rueda C. G. M., Lo'pez A. D., Solis-Moya E., Carvaja A. V. Grain and flour wheat quality modified by genotype, availability of nitrogen, and growing season. International Journal of Agronomy. 2020. P. 1-9.

7. Sobolewska M., Wenda-Piesik A., Jaroszewska A., Stankowski S. Effect of habitat and foliar fertilization with $\mathrm{K}, \mathrm{Zn}$ and $\mathrm{Mn}$ on winter wheat grain and baking qualities. Agronomy. 2020. Vol. 10, Iss. 2. P. 276-297.

8. Завадська О. В., Байба Т. А. Якість зерна пшениці озимої м'якої різних сортів. Modern Engineering and Innovative Technology. 2019. № 07-02. C.20-23.

9. Kulig B., Lepiarczyk A., Andrzej O., Kołodziejczyka M. The effect of tillage system and forecrop on the yield and values of LAI and SPAD indices of spring wheat. European Journal of Agronomy. 2010. Vol. 33, Iss. 1. P. 43-51.

10. Рослинництво України 2019. Статистичний збірник / за ред. в середньому за роками досліджень, строками сівби та попередниками.

О. Прокопенка. Київ: Державна служба статистики України, 2020. 183 с.

11. Habibi A., Fazily T. Effectt of sowing dates on growth, yield attributes and yield of four wheat varieties. EPRA International Journal of Research and Development. 2020. Vol. 5, Iss. 1. P. 56-59.

12. Гудзенко В. Н. Статистическая и графическая (GGE biplot) оценка адаптивной способности и стабильности селекционных линий ячменя озимого. Вавиловский журнал генетики и селекции. 2019. Т. 23, № 1. С. 110-118.

13. Правдзіва I. В., Демидов О. А., Гудзенко В. М., Дергачов О. Л. Оцінювання врожайності та стабільності генотипів пшениці м'якої озимої (Triticum aestivum L.) залежно від попередників та строків сівби. Plant Varieties Studying and protection. 2020. Vol. 16, No 3. C. 291-302.

14. Жемела Г. П., Шакалій С. М. Вплив попередників на врожайність та якість зерна пшениці м'якої озимої. Вісник Полтавської державної аграрної академії. 2012. № 3. С. $20-22$.

15. Технологія виробництва насіння пшениці озимої (Методичні рекомендації) / за ред. кандидатів с.-г. наук А. А. Сіроштана, В. П. Кавунця. Київ: ТОВ ЦП Компринт, 2016. 92 с.

16. ЗЕРНО. Метод определения натуры: ГОСТ 10840-64. [Действующий от 1965-07-01]. Москва: Стандартинформ, 2009. 3 с. (Межгосударственный стандарт)

17. Parvej M. R., Holshouser D. L., Kratochvil R. J., Whaley C. M., Dunphy E. J., Roth G. W., Faé G. S. Early high-moisture wheat harvest improves double-crop system: I. Wheat yield and quality. Crop Science. 2020. Vol. 60, Iss. 5. P. 2633-2649.

18. Twizerimana A., Niyigaba E., Mugenzi I., Ngnadong W. A., Li Ch., Hao T. Q., Shio B. J., Hai J. B. The combined effect of different sowing methods and seed rates on the quality features and yield of winter wheat. Agriculture. 2020. Vol. 10, Iss. 5. P. 153-173.

19. Протопіш I. Г. Оцінювання взаємозв'язків показників якості зерна 
Демидов О. А., Гудзенко В. М., Правдзіва І. В., Василенко Н. В., Дергачов О. Л., Заїма О.А.

пшениці озимої. Вісник аграрної науки. 2016. Т. 94. №3. С. 72-75.

\section{References}

1. Denčić, S., Mladenov, N., Kobiljski, B. (2011). Effects of genotype and environment on breadmaking quality in wheat. International Journal of Plant Production, 5 (1), 7171-82. doi: 10.22069/IJPP.2012.721

2. Ulianych, I. F. (2020). Krup'iani vlastyvosti zerna pshenytsi m'iakoi ozymoi zalezhno vid sortu [Grits properties of soft winter wheat grain depending on variety]. Journal of Uman NUH, 96 (1), 572-582. doi: 10.31395/2415-8240-2020-96-1-572-582

3. Deivasigamani, S., Swaminathan, C. (2018). Evaluation of seed test weight on major field crops. International Journal of Research Studies in Agricultural Sciences, 4 (1), 8-11. doi: 10.20431/2454-6224.0401001

4. Costa, R., Pinheiro, N., Almeida, A. S., Gomes, C., Coutinho, J., Coco, J., Costa, A., Maçãs, B. (2013). Effect of sowing date and seeding rate on bread wheat yield and test weight under Mediterranean conditions. Emir. J. Food Agric, 25 (12), 951-961. doi: 10.9755/ejfa.v25i12.16731

5. Lychko, N. M. (2013). Standartizatsiya i podtverzhdeniye sootvetstviya sel'skokhozyaystvennoy produktsii [Standardization and confirmation of conformity of agricultural products]. Uchebnik dlya vuzov [Textbook for universities]. Moscow: DeLi plyus, 512.

6. Valde's, C. V., Estrada-Campuzano, G., Rueda, C. G. M., Lo'pez, A. D., SolisMoya, E., Carvaja, A. V. (2020). Grain and flour wheat quality modified by genotype, availability of nitrogen, and growing season. International Journal of Agronomy, 1-9. doi: $\underline{10.1155 / 2020 / 1974083}$

7. Sobolewska, M., Wenda-Piesik, A., Jaroszewska, A., Stankowski, S. (2020). Effect of habitat and foliar fertilization with $\mathrm{K}, \mathrm{Zn}$ and $\mathrm{Mn}$ on winter wheat grain and baking qualities. Agronomy, 10 (2), 276-297. doi: $\underline{10.3390 / \text { agronomy } 10020276}$

8. Zavads'ka, O. V., Baiba, T. A. (2019). Yakist' zerna pshenytsi ozymoi m'iakoyi riznykh sortiv [Quality of grain wheat winter soft of the different varieties]. Modern Engineering and Innovative Technologies, 2
(07-02), 20-23. doi: 10.30890/25675273.2019-07-02-026

9. Kulig, B., Lepiarczyk, A., Andrzej, O., Kołodziejczyka, M. (2010). The effect of tillage system and forecrop on the yield and values of LAI and SPAD indices of spring wheat. European Journal of Agronomy, 33 (1), 43-51. doi: 10.1016/j.eja.2010.02.005

10. Prokopenko, O. (Ed.). (2020). Roslynnytstvo Ukrainy 2019 [Crop production of Ukraine 2019]. Statystychnyy zbirnyk [Statistical yearbook]. Kyiv: Derzhavna sluzhba statystyky Ukrainy, 183.

11. Habibi, A., Fazily, T. (2020). Effectt of sowing dates on growth, yield attributes and yield of four wheat varieties. EPRA International Journal of Research and Development, 5 (1), 56-59. doi: 10.36713/epra3895

12. Gudzenko, V. N. (2019). Statisticheskaya i graficheskaya (GGE biplot) otsenka adaptivnoy sposobnosti i stabil'nosti selektsionnykh liniy yachmenya ozimogo [Statistical and graphical (GGE biplot) evaluation of the adaptive ability and stability of winter barley breeding lines]. Vavilov Journal of Genetics and Breeding, 23 (1), 110 118. doi: 10.18699/VJ19.469.

13. Pravdziva, I. V., Demydov, O. A., Hudzenko, V. M., Derhachov, O. L. (2020). Otsiniuvannia vrozhainosti ta stabil'nosti henotypiv pshenytsi m'iakoi ozymoi (Triticum aestivum L.) zalezhno vid poperednykiv ta strokiv sivby [Evaluation of yield and stability of bread winter wheat genotypes (Triticum aestivum L.) depending on predecessors and sowing dates]. Plant Varieties Studying and Protection, 16 (3), 291-302. doi: 10.21498/2518-1017.16.3.2020.214923

14. Zhemela, H. P., Shakaliy, S. M. (2012). Vplyv poperednykiv na vrozhaynist' ta yakist' zerna pshenytsi m'iakoi ozymoi [Influence of precursors on grain yield and quality of soft winter wheat]. Bulletin of Poltava State Agrarian Academy, 3, 20-22. doi: 10.31210/visnyk2012.03.03

15. Siroshtan, A. A., Kavunets', V. P. (Eds.). (2016). Tekhnolohiya vyrobnytstva nasinnya pshenytsi ozymoyi (Metodychni rekomendatsiyi) [Technology of production of winter wheat seeds (Methodical 
Демидов О. А., Гудзенко В. М., Правдзіва І. В., Василенко Н. В., Дергачов О. Л., Займа О.А.

recommendations)]. Kyiv: TOV TSP Komprynt, 92.

16. Zerno. Metod opredeleniya natury [Grain. Methods for determination of hectolitre weight: Interstate standard 10840-64]. (2009). Moscow: Standartinform, 3.

17. Parvej, M. R., Holshouser, D. L., Kratochvil, R. J., Whaley, C. M., Dunphy, E. J., Roth, G. W., Faé, G. S. (2020). Early highmoisture wheat harvest improves double-crop system: I. Wheat yield and quality. Crop Science, 60 (5), 2633-2649. doi: $\underline{10.1002 / \csc 2.20172}$
18. Twizerimana, A., Niyigaba, E., Mugenzi, I., Ngnadong, W. A., Li, Ch., Hao, T. Q., Shio, B. J., Hai, J. B. (2020). The combined effect of different sowing methods and seed rates on the quality features and yield of winter wheat. Agriculture, 10 (5), 153-173. doi: 10.3390 /agriculture 10050153

19. Protopish I. H. (2016). Otsiniuvannia vzaiemozv'iazkiv pokaznykiv yakosti zerna pshenytsi ozymoi [Assessment of correlation of quality factors of winter wheat]. Bulletin of Agricultural Science, 94 (3), 72-75. doi: 10.31073/agrovisnyk201603-15

\section{ФОРМИРОВАНИЕ И ВАРИАБЕЛЬНОСТЬ НАТУРНОЙ МАССЫ ЗЕРНА ГЕНОТИПОВ ПШЕНИЦЫ МЯГКОЙ ОЗИМОЙ (Triticum aestivum L.) В ЗАВИСИМОСТИ ОТ УСЛОВИЙ ГОДА, ПРЕДШЕСТВЕННИКОВ И СРОКОВ СЕВА}

\section{А. А. Демидов, В. Н. Гудзенко, И. В. Правдзива, Н. В. Василенко,}

\section{А. Л. Дергачов, А. А. Заима}

Аннотация. Целью исследования - выявить особенности формирования и вариабельности натурной массы зерна генотипов пшеницы мягкой озимой в зависимости от условий года, срока сева и различных предшественников. Исследования проведень в Мироновском институте пшеницы имени В. Н. Ремесло НААН Украинь в 2016/17-2018/19 г2. Оиенили 17 генотипов пшеницы мягкой озимой, которые высевали в три срока после пяти предшественников. Натуру зерна определяли согласно ГОСТ 10840-64. Статистическую обработку данных проводили с использованием программ Statistica 8.0, Excel 2013. Выявлено существенное влияние условий года выращивания на натуру зерна сортов пшенищь мягкой озимой в условиях центральной Лесостепи Украины. Отмечены достоверные различия по реакиии исследованных генотипов на сроки сева после различных предшественников. Наибольшее влияние сроков сева на натуру зерна отмечено в сорта МІП Відзнака, предшественников - в сортов МІП Ювілейна, Подолянка, МІП Лада, МІП Дарунок. В общем, максимальной натура зерна была после предшественника сидеральный пар, наименьшая - после сои. Выявлена общая тендениия уменьшения натуры зерна со смещением срока сева от 26 сентября до 16 октября после предшественников сидеральный пар, горчица, подсолнечник, соя. Оптимальным был срок сева 5 октября для сортов МІП Валенсія, Естафета миронівська, МІП Лада после предшественника сидеральный пар; после горчиць - для сортов Подолянка, Трудівниия миронівська, Грачія миронівська, МІП Дніпрянка, МІП Лада; после подсолнечника - сортов Подолянка, Трудівниия миронівська, Балада миронівська, Грація миронівська, МІП Ассоль; после кукурузы - сортов Трудівничя миронівська, Естафета миронівська; после сои - Подолянка, Трудівниця миронівська. Выделены сорта 
Демидов О. А., Гудзенко В. М., Правдзіва І. В., Василенко Н. В., Дергачов О. Л., Займа О.А.

МІП Вишиванка, Трудівничя миронівська, Балада миронівська, Естафета миронівська, МІП Дніпрянка, МІП Відзнака и МІП Ювілейна, которые достоверно превышали стандарт Подолянка по натуре зерна в среднем по годам исследований, срокам сева и предшественникам.

Ключевые слова: пиеница мягкая озимая, натура зерна, срок сева, предшественник, $A N O V A$

\title{
FORMATION AND VARIABILITY OF TEST WEIGHT IN WINTER BREAD WHEAT GENOTYPES (Triticum aestivum L.) DEPENDING ON THE GROWING SEASON CONDITIONS, PRECEDING CROPS AND SOWING DATES

\author{
O. A. Demydov, V. M. Hudzenko, I. V. Pravdziva, N. V. Vasylenko, \\ O. L. Derhachov, O. A. Zaima
}

\begin{abstract}
The study aimed to identifying peculiarities of formation and variability of grain test weight in winter bread wheat genotypes depending on the growing season conditions, sowing dates and different preceding crops. The studies were conducted at The V.M. Remeslo Myronivka Institute of Wheat of the NAAS of Ukraine during 201617-2018-19 growing seasons. There were estimated 17 winter bread wheat genotypes that were sown in three sowing dates after five preceding crops. Test weight was evaluated according to the State Standard 10840-64. Statistical processing was performed with using programs Statistica 8.0, Excel 2013. It was revealed the significant effect of growing season conditions on grain test weight in winter bread wheat varieties in environments of Ukrainian Forest-Steppe. Significant differences in responses of the genotypes under study on sowing date after different preceding crops were revealed. The most effect of sowing dates on test weight was established in the variety MIP Vidznaka, while the most effect of preceding crops was established in the varieties MIP Yuvileina, Podolianka, MIP Lada, and MIP Darunok. In general, maximal test weight was formed after green manure and the minimal one was after soybeans as preceding crop. The general tendency of decrease in grain test weight with shift in sowing dates from September 26 to October 16 after preceding crops green manure, mustard, sunflower, soybeans was revealed. The sowing date October 05 was optimal for the varieties MIP Valensiia, Estafeta myronivska, MIP Lada after green manure, for the varieties Podolianka, Trudivnytsia myronivska, Hratsiia myronivska, MIP Dniprianka, MIP Lada after mustard, for the varieties Podolianka, Trudivnytsia myronivska, Balada myronivska, Hratsiia myronivska, MIP Assol after sunflower, for the varieties Trudivnytsia myronivska, Estafeta myronivska after maize, for the varieties Podolianka, Trudivnytsia myronivska after soybeans. The varieties MIP Vyshyvanka, Trudivnytsia myronivska, Balada myronivska, Estafeta myronivska, MIP Dniprianka, MIP Vidznaka, and MIP Yuvileina were identified which exceeded significantly the standard variety Podolianka in test weight on average by years of the research, sowing dates, and preceding crops.
\end{abstract}

Key words: winter bread wheat, test weight, sowing date, preceding crops, ANOVA 